\title{
Genetic Variability Induced by Gamma Radiation in Cowpea [(Vigna unguiculata L. (Walp)] in Burkina Faso
}

\begin{abstract}
Karidiatou Gnankambary, Msc
Université Joseph KI-ZERBO, Ecole Doctorale Sciences et Technologies, Laboratoire Biosciences, Equipe Génétique et Amélioration des Plantes (EGAP), Ouagadougou, Burkina Faso Institut de l'Environnement et de Recherches Agricoles (INERA), CREAF de Kamboinsé Département Productions Végétales, Laboratoire de Génétique et de Biotechnologies Végétales, Ouagadougou, Burkina Faso
\end{abstract}

Teyoure Benoit Joseph Batieno, PhD

Institut de l'Environnement et de Recherches Agricoles (INERA), CREAF de

Kamboinsé Département Productions Végétales, Laboratoire de Génétique et de Biotechnologies Végétales, Ouagadougou, Burkina Faso

\section{Nerbewende Sawadogo, PhD}

Université Joseph KI-ZERBO, Ecole Doctorale Sciences et Technologies, Laboratoire Biosciences, Equipe Génétique et Amélioration des Plantes

(EGAP), Ouagadougou, Burkina Faso

Mahamadou Sawadogo, Prof.,

Université Joseph KI-ZERBO, Ecole Doctorale Sciences et Technologies, Laboratoire Biosciences, Equipe Génétique et Amélioration des Plantes

(EGAP), Ouagadougou, Burkina Faso,

\section{Jean Baptiste Tignegre, PhD \\ Djibril Yonli, PhD \\ Tinga Jeremy Ouedraogo, PhD}

Institut de l'Environnement et de Recherches Agricoles (INERA), CREAF de

Kamboinsé Département Productions Végétales, Laboratoire de Génétique et de Biotechnologies Végétales, Ouagadougou, Burkina Faso

Doi: 10.19044/esj.2019.v15n15p153 URL:http://dx.doi.org/10.19044/esj.2019.v15n15p153

\begin{abstract}
Cowpea is a good source of protein, minerals, and vitamins in most developing countries in Africa. However, this legume production is still limited by various biotic and abiotic constraints. Beyond these constraints, the pressure of conventional breeding methods on natural variability exhausted a narrow genetic base of cowpea. Therefore, it is important to
\end{abstract}


explore other ways of broadening the genetic base of the crop. Gamma irradiation is an alternative to increase genetic variability and improve the genetic base of crops. This paper focuses on evaluating the level and structuring of agro-morphological variability induced by gamma radiation among M2 plants of cowpea genotype. So, Tiligre, Moussa local, and KVx396-4-5-2D genotypes were treated with $150 \mathrm{~Gy}$ of gamma rays. The M2 generation was then screened for genetic variability. Thus, 38 M1 plants (either 38 x 10 seeds) by genotypes are advanced to the M2 generation based on the plant by line method. Four (04) agro-morphological parameters were used to assess phenotypical variability. Analysis of variance showed a highly significant difference between the families of plants except those of $\mathrm{KVx}$ 396-4-5-2D for the flowering time. The maximum variability was observed for the number of branches and the length of the peduncles with a very high coefficient of variation. A high broad-sense heritability was recorded for all measured traits $(>75 \%)$ of Moussa Local; for plant height $(81.1 \%)$ of KVx396-4-5-2D, for first flower date (80.2\%), and peduncles length $(78.6 \%)$ of Tiligre. Based on phenotypic characters, the principal component analysis (PCA) and the cluster analysis showed variation among genotypes irradiated, and they were grouped into four clusters in $\mathrm{KVx}-396-4-5-2 \mathrm{D}$, six clusters in Moussa local and Tiligre populations. So, 150 Gy dose of $\gamma$-rays was effective to induce variability in morphological and phenological characters within cowpea genotypes.

Keywords: Vigna unguiculata, $\gamma$-rays, mutants, genetic diversity

\section{Introduction}

Cowpea [Vigna unguiculata (L.) Walp.] is a tropical grain legume which plays an important role in developing countries of Africa. It is an important source of protein, one that is rich in leucine, isoleucine, lysine, tyrosine, and phenylalanine (Elhardallou et al., 2015). Cowpea grains contain vitamins and mineral elements (Zia-ul-haq et al., 2012) which are useful in solving children's malnutrition in sub-Saharan Africa. This legume has antioxidant and anti-free radical properties and contributes to preventing degenerative diseases caused by free radicals (Zia-ul-haq et al., 2013). In addition to human nutrition, cowpea fodder is an excellent source of protein for animal feed. On the other hand, cowpea can fix 52 to $56 \%$ of atmospheric nitrogen, thereby raising soil mineral nitrogen from 13 to $40 \%$ (Bado et al., 2002). Indeed, cowpea has important food and agronomic values. However, its yield is still low in Burkina Faso due to various abiotic and biotic constraints among which are the drought and the parasitic weed Striga gesnerioides. Most cowpea breeding programs for resistance to this weed used conventional breeding methods exploiting only the natural variability 
available. Selection within germplasm for a long time exhausted the genetic variability of the legume crop (Amri-Tilioune et al., 2018). Adequate variability is not available to improve cowpea production because of the lower genetic pool (Batieno et al., 2018). Therefore, mutation breeding is an alternative solution to producing variant mutant form. Induced mutation can be efficiently used as an alternative to induce genetic variability (Malek et al., 2014; Olasupo et al., 2018). For quite a long time now, the use of mutagens has been proven to be beneficial in cowpea (Micke, 1993), and in groundnut (Gunasekaran \& Paravadai, 2015). However, mutation breeding of cowpea and mutant cultivars in Burkina Faso is scarce. Therefore, this study was aimed at selecting a novel mutation in cowpea in the M2 generation of three genotypes populations (KVx-396-4-5-2D, Moussa local, Tiligre) in order to broaden the genetic base of cowpea for better improvement for biotic and abiotic stresses.

\section{Material and Methods Experimental Site}

The present study was done at Kamboinse research station of the "Institut de 1'Environnement et de Recherches Agricoles" (INERA) in Burkina Faso. The station is located at $12 \mathrm{Km}$ from Ouagadougou on Kongoussi road (RN 22) with geographical coordinates of $12^{\circ} 26^{\prime} 59.4^{\prime}$ 'north latitude: $1{ }^{\circ} 33^{\prime} 08.0$ ' ' west. In addition, it has an altitude of $296 \mathrm{~m}$ above sea level in the Centre Region in Burkina Faso.

\section{Plant Material and Population Development}

Seeds of three cowpea genotypes, Tiligre, Moussa local and $\mathrm{KVX}$ 396-4-5-2D, developed by INERA were used in the present study. One-yearold seeds (harvested in 2015) were treated with gamma-ray at dose 150 Gray (Gy) using a labeled Cobalt source (60CO) in the laboratory of the International Atomic Energy Agency (IAEA) in Seibersdorf, Austria. This dose was chosen because germination assays indicated that $150 \mathrm{~Gy}$ corresponded to the optimal dose which induced $50 \%$ of seed germination of the three genotypes used. The treated seeds were planted to generate M1 plants in the field. Untreated seeds of the three genotypes were used as controls. The distance between and within rows was $80 \mathrm{~cm}$ x $15 \mathrm{~cm}$. The seeds of individually harvested M1 plants were sown to produce M2 generation using the plant M1-line method. Planting was done in pots $(10 \mathrm{~L})$ filled with the mixture of sandy and loamy soil. One seed was planted per pot in the greenhouse. Planting was done on $19^{\text {th }}$ October 2016. NPK fertilization (1423-14) and phytosanitary treatments at K-Optimal (active ingredient) and Deltacal were applied. 


\section{Data Collection}

Data collected on the individual plants were required for $50 \%$ flowering and included plant height (HP), peduncles length (LP), and branches number (NR). The first flower day (DPF) was also recorded. The first flower time corresponded to the number of dates from sowing to the appearance of the first flower. Plant height was measured from the soil level of the plant to apex. The average peduncle length randomly measured on three peduncles. Also, the number of primary branches was also counted.

\section{Statistical Analysis}

The data collected were subjected to the "linear model" and the student test using SAS version 8 software to estimate the level of variability within each genotype. The broad-sense heritability $\left(\mathrm{H}^{2}\right)$ was calculated according to the formula used by Dilnesaw et al. (2013) and was assessed according to the scale used by Nair et al. (2014) in order to estimate genetic and non-genetic factors. Genetic diversity analysis was performed using principal component analysis and hierarchical method for clustering the mutants.

\section{Results and Discussion}

\section{Agro-morphological Variation}

Results of Analysis of variance and value of genetic parameters were recorded in Table 1 . A very highly significant difference for all measured traits in the M2 population of the three evaluated genotypes KVx396-4-5-2D, Moussa local, and Tiligre were observed. Results revealed a high coefficient of variation for the characters number of branches (27 to 61\%) and the length of the peduncles (39 to 54\%). Thus, a low value was recorded for the plant height (12 to $14 \%$ ) and flowering date (6 to $12 \%$ ). The value of genetic parameters differed from quantitative characters. So, Broad-sense heritability in $\mathrm{M} 2$ generation ranged from 34 to $82 \%$. High broad sense heritability was recorded for branches number $(81.4 \%)$, peduncle length $(80.5 \%)$, plant height (76.6\%), and first flowering date (76.8\%) in the M2 population from Moussa local. In Tiligre population, a high value was observed for peduncle length (78.6\%) and first flower date $(80.2 \%)$; whereas it was moderate for the number of branches (54.2\%) and plant height (54.6\%). KVx396-4-5-2D recorded high heritability for plant height $(81.1 \%)$, moderate heritability for the number of branches $(55.7 \%)$, peduncle length $(53.5 \%)$, and low heritability for first flower date (34.5\%). According to the Student-NewmanKeuls test, the families of plants statistically different from their checks were determined for the four agronomic characters. On this basis, early and late flowering plants, tall and short, branched and long-peduncled plants were distinguished (Table 2). The results revealed a large range of morphological 
and phenological variation with the ample diversity in flowering, plant height, peduncle length, and the number of branches. The maximum variation is observed for the number of branches and for the peduncle length. In Moussa local population, the four characters were highly heritable. Whereas, only peduncle length and first flower date of Tiligre plant and plant height of KVx396-4-5-2D were highly heritable.

Gamma radiation has induced the genetic variability in cowpea. 150 Gy dose of $\gamma$-rays was effective for inducing variability of morphological and phenological characters in cowpea. Induced variability by mutagen has been observed in many crops. Indeed, the agro-morphological diversity induced by gamma irradiation and high heritability were reported in Cowpea by Adekola and Oluleye (2007) and by Nair and Mehta (2014). In black gram, it was also reported by Usharani et al. (2015) and Usharani et al. (2016). The heritability level of the characters varied with the genotypes and also the environmental conditions of the experience. The high broad-sense heritability value indicated the predominance of additive gene action in the expression of these characters (Manggoel et al., 2012). Their variation was due to the mutation of more than one locus (Amri-Tiliouine et $a l ., 2018$ ). The variability of agromorphological characters in cowpea after irradiation with gamma-ray are genetically controlled. So, these characters are less influenced by environmental change and could be used in the breeding program. However, the moderate and low heritability characters indicated that environmental effects and phenotypic selection will be less effective for such character. Increased genetic variability provides a great possibility for future selection. Mutagen would be an excellent tool for creating variability and for developing superior genotypes.

Table 1. Descriptive statistics and estimated genetic parameters in population M2 of KVx396-4-5-2D, Moussa local and Tiligre

\begin{tabular}{llllllll} 
Varieties & Characters & Mean & CV & Prob & GV & PV & $\mathrm{H}^{2}(\%)$ \\
\hline \multirow{5}{*}{ KVx396-4-5-2D } & HP & 21.73 & 12.66 & 0.0001 & 2.90 & 3.58 & 81.1 \\
& NR & 3.74 & 55.49 & 0.0001 & 0.26 & 0.46 & 55.7 \\
& DPF & 49.52 & 11.40 & 0.0347 & 0.80 & 2.31 & 34.5 \\
& LP & 9.15 & 44.49 & 0.0003 & 0.91 & 1.70 & 53.5 \\
\hline \multirow{5}{*}{ Tiligre } & HP & 28.57 & 12.50 & 0.0001 & 0.90 & 1.65 & 54.6 \\
& NR & 2.13 & 60.79 & 0.0001 & 0.12 & 0.22 & 54.2 \\
& DPF & 53.16 & 6.64 & 0.0001 & 2.98 & 3.71 & 80.2 \\
& LP & 7.13 & 39.40 & 0.0001 & 1.70 & 2.17 & 78.6 \\
\hline \multirow{5}{*}{ Moussa local } & HP & 28.04 & 13.23 & 0.0001 & 2.25 & 2.94 & 76.6 \\
& NR & 4.35 & 27.77 & 0.0001 & 0.32 & 0.39 & 81.4 \\
& DPF & 45.95 & 7.44 & 0.0001 & 1.93 & 2.52 & 76.8 \\
& LP & 8.43 & 53.01 & 0.0001 & 4.13 & 5.13 & 80.5 \\
\hline
\end{tabular}

Legend: HP: Height of plants at flowering; NR: Number of branches at flowering; DPF:

Date of the first flower; LP: peduncle length; CV: coefficient of variation; Prob: probability, GV; GenotypicVariance; PV: phenotypic Variance; $H^{2}$ : broad sense heritability 
Table 2. Variation of Parameters in M2 population of KVx396-4-5-2D,

Moussa local and Tiligre

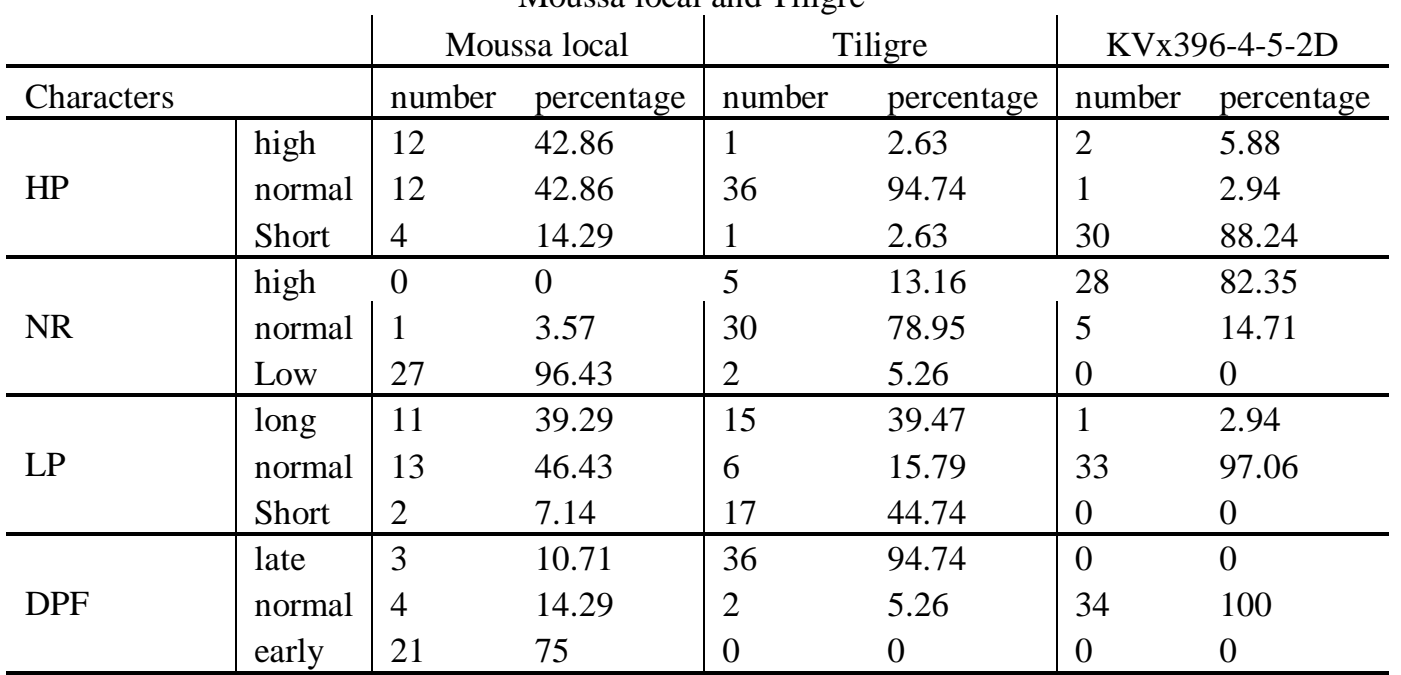

Legend: $H P$, height of plants at flowering; NR, number of branches at flowering; DPF, date of the first flower; LP, peduncle length; $C V$, coefficient of variation; Prob., probability; $G V$, genotypic variance; $P V$, phenotypic variance; $H^{2}$, broad sense heritability

\section{M2 Population Structure}

The principal component analysis (PCA) revealed the relationship between the evaluated parameters and the similarities between the mutants. In the three populations, the main component analysis on quantitative data shows a high significance of Bartlett test $(\mathrm{p}<0.0001)$ and the eigenvalues of the axes. Table 3 shows that 2 axes explain most of the variability. Most of the variability (70.5\%) in KVx396-4-5-2D population was explained by the two axes (1 and 2). The first axis explains $47.5 \%$ of the variability defined by the variables related to the length of the peduncle and the date of the first flowering. The second axis which revealed $23 \%$ of the variability is related to the plant height and the number of primary branches. Therefore, axis 1 allowed helps in distinguishing the mutants of KVx396-4-5-2D as having a long stalk and as a late flowering. On the other hand, axis 2 has identified mutants that are of high size and ramified.

As for the local Moussa population, the principal component analysis (PCA) showed most of the variability (70.3\%) explained by the two first axes. The contribution of axis 1 of $44.5 \%$ is related to the length variables of the stalk, the date of the first flowering, and the number of primary branches; while axis $2(25.8 \%)$ is related to the height of the plants. Axis 1 distinguishes the mutants characterized by a high number of primary branches, a long stalk, and late flowering and axis 2 identified the high-size mutants.

The contribution of the two axes to the variability of the population of Tiligre is $62.5 \%$. The first axis explains $36.2 \%$ of the variability. It is defined 
by the length of the peduncle and the date of the first flowering. This axis characterizes mutants with a long stalk and late flowering. Axis 2 represented by the number of primary branches and the plant height explains $26.3 \%$ of the variability. This axis identifies the mutants of high size and ramified. The clouds of the individuals projected on the F1 axis and the F2 axis, shows variability within the irradiated populations of KVx396-4-5-2D (Figure 1a) of Moussa local (Figure 2a) and of Tiligre (Figure 3a). Using similarity, the hierarchical analysis allows the grouping of the mutants. So, the KVx396-45-2D mutant population was classified into four clusters (Figure 1b), whereas local Moussa (Figure 2b) and Tiligre (Figure 3b) are grouped into six clusters. The cluster organizes individuals as endpoints that have joined a new point, with drawn lines that represent membership. Longer lines represent a greater distance between clusters. Morphological and phenological characteristics and number of families vary with clusters and with genotypes (Table 4). In $\mathrm{KVx} 396-4-5-2 \mathrm{D}$ population, cluster 3 is the largest one with 172 families. It is followed by cluster 2 with 152 families including control, and then cluster 4 with 61 families. The smallest group identified was cluster 1 with 48 families. The mutant families included in clusters 1, 3, and 4 were characterized with small size, a short stalk, and late flowering. In contrast, the mutants of cluster 1 exhibited a high number of branching and those of Group 4 shows a very late flowering.

In Moussa local population, cluster 1 was the largest groups with 150 families, followed by cluster 2 with 100 families, cluster 6 with 83 families, and clusters 4 with 59 families. Cluster 3 included control and cluster 5 was the smallest registered, with 50 and 3 families respectively. The mutant families of groups 1, 2, 4, 5, and 6 showed high-sized families with a small number of branches. In addition, Group 1 and 2 had a short peduncle and a slightly delayed flowering, while Group 4 has a long peduncle and a slightly early flowering. Families with a very long peduncle and a slightly delayed flowering were in Group 5, while families with short peduncle and late flowering were in Group 6.

Finally, in Tiligre population, the six groups registered 68, 70, 68, 64, 75 and 76 families respectively. Group 4 brought together families similar to the witness. Except for Group 3, groups 1, 2, 5, and 6 had high mean values for plant height. Group 1, 2, and 3 exhibited the longer peduncle, while 5 and 6 had the shorter peduncle. The high number of branches is only recorded in clusters 1, 3, and 5. All groups exhibited late flowering.

The results of the cluster analysis confirm the presence of genetic differences between mutant families. In Moussa local population, in particular, mutant families in cluster 1 with high number of branching could be useful for improving cowpea yield, families in cluster 4 and 5 would be suitable for harvesting by machines, and the cluster 4 would be also useful 
for the improvement of early flowering. In Tiligre population, cluster 1 and 2 would be suitable for machine harvesting and the families in clusters 1, 3, and 5 would be useful for agronomic performance. The selected mutants show useful agronomic traits capable of conferring on them the selective advantage for increased yield. The agronomical advantage of higher branching was reported by Adekola et al. (2007). Kumara (2011) reported a positive correlation between higher branching and seed yields. A positive correlation between plant height and yield component was also reported by Kumara (2011). Early flowering mutants may be interesting for the areas with short rainfall duration as they show better tolerance to drought. Long peduncles will be interesting for easy harvesting by manual or mechanical means (Olasupo et al., 2018). It could be a strategy to reduce the cost of cultivation. Overall, gamma-ray mutation induction is useful for creating a new source of variability. The 150 Gy of gamma rays on KVx396-4-5-2D, Moussa local, and Tiligre is effective in generating significant variability for most of the quantitative traits studied. The high induced genetic variability is useful for the enhancement of Cowpea reproduction.

Table 3. Eigenvectors-eigenvalues and accumulated variation of the first four principal components (PC)

\begin{tabular}{llllll}
\hline Varieties & Characters & F1 & F2 & F3 & F4 \\
\hline \multirow{4}{*}{ Moussa } & HP & 0.19567 & 0.90969 & 0.23162 & -0.2838 \\
& NR & 0.50099 & -0.3627 & 0.76084 & -0.1964 \\
& LP & 0.61613 & 0.1412 & -0.1418 & 0.7618 \\
& DPF & -0.5754 & 0.14472 & 0.58939 & 0.54825 \\
\hline \multirow{4}{*}{ KVx396-4-5-2D } & HP & 0.32938 & 0.8753 & 0.31105 & -0.1691 \\
& NR & 0.40553 & -0.4346 & 0.80391 & 0.01888 \\
& LP & 0.61562 & 0.02019 & -0.3166 & 0.72138 \\
& DPF & -0.59 & 0.211 & 0.39592 & 0.67132 \\
\hline \multirow{4}{*}{ Tiligre } & HP & 0.15813 & 0.70135 & -0.6944 & 0.03003 \\
& NR & 0.3559 & 0.58467 & 0.65798 & -0.3139 \\
& LP & 0.69072 & -0.1173 & 0.06948 & 0.71015 \\
& DPF & -0.6093 & 0.39052 & 0.28289 & 0.62947 \\
\hline
\end{tabular}



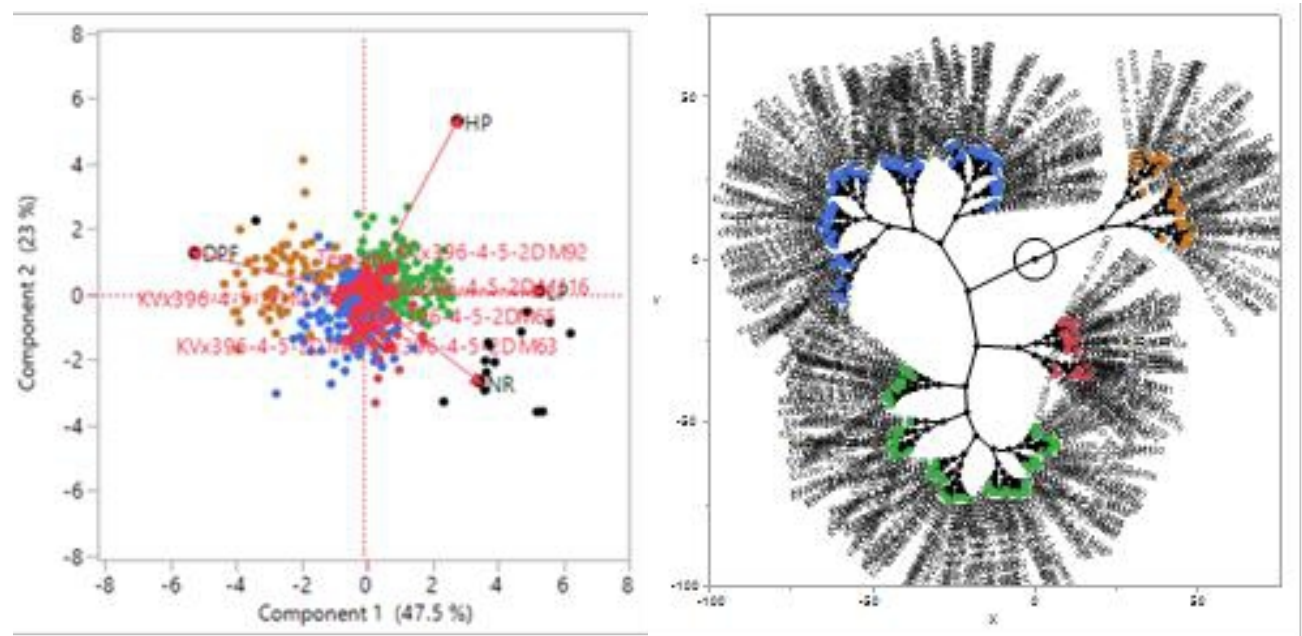

Figure 1. Representation of genotype-trait biplot (a) and cluster constellation plot of KVx396-4-5-2D

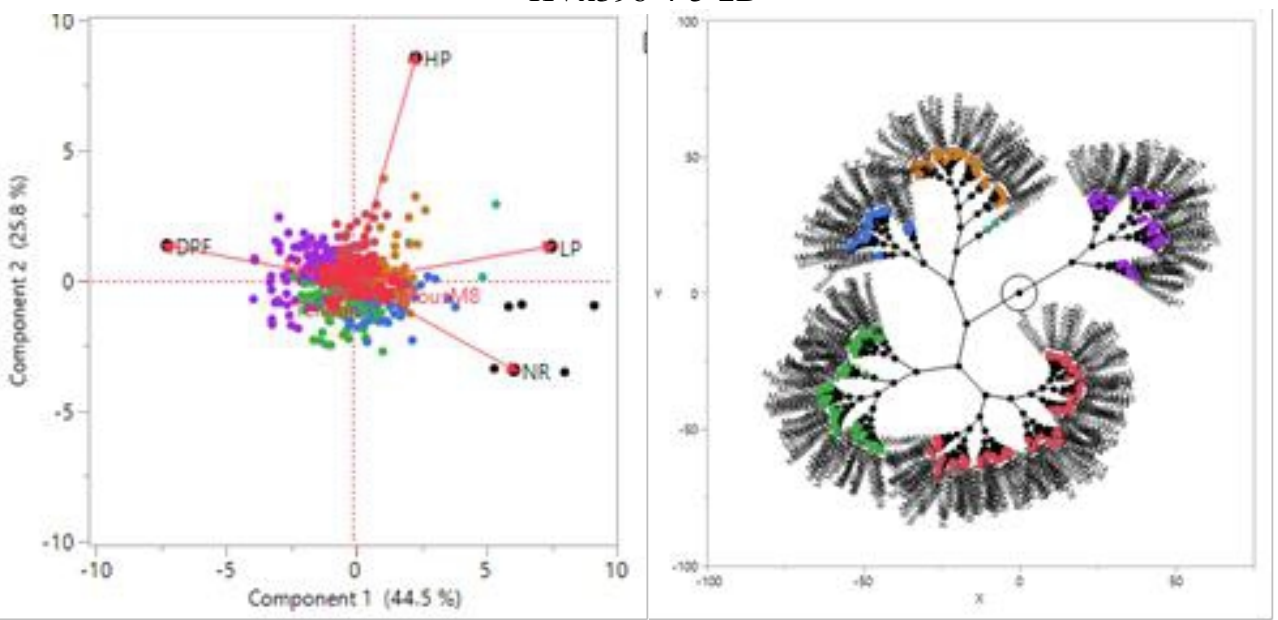

Figure 2. Representation of genotype-trait biplot (a) and cluster constellation plot of Moussa mutants 

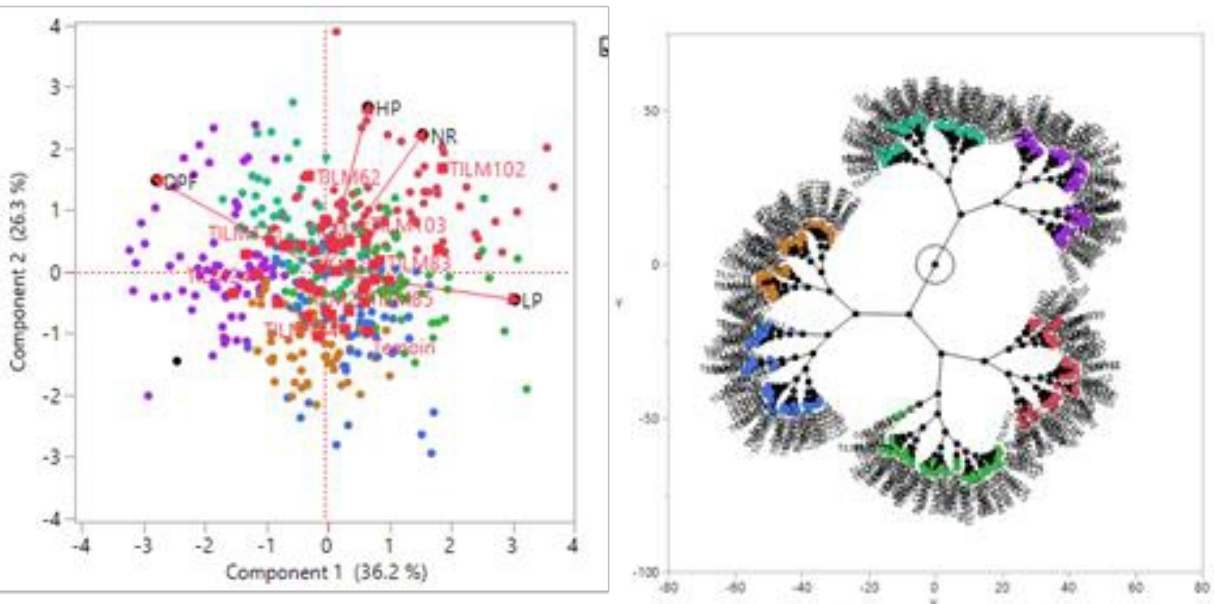

Figure 3. Representation of genotype-trait biplot (a) and cluster constellation plot of Tiligre mutants (b)

Table 4. Mean values of clusters formed by hierarchical clustering

\begin{tabular}{lllllll} 
& Cluster & Count & HP & NR & LP & DPF \\
\hline \multirow{4}{*}{ Kvx396-4-5-2D } & 1 & 48 & 28.7917 & 5.6875 & 8.3021 & 49.5 \\
& 2 & 152 & 33.2621 & 4.0263 & 11.4489 & 46.6447 \\
& 3 & 172 & 27.218 & 3.1802 & 8.2195 & 47.8895 \\
& 4 & 61 & 28.8197 & 2.5246 & 4.2158 & 61.1639 \\
\hline \multirow{4}{*}{ Moussa local } & 1 & 150 & 30.4407 & 4.2933 & 7.6566 & 45.4733 \\
& 2 & 100 & 23.8961 & 3.97 & 6.9317 & 44.51 \\
& 3 & 50 & 26.6334 & 6.62 & 9.7799 & 44.3 \\
& 4 & 59 & 29.8983 & 4.9322 & 14.5537 & 43.5254 \\
& 5 & 3 & 31.6667 & 4.6667 & 37.1333 & 44.6667 \\
Tiligre & 1 & 63 & 28.1773 & 3.0964 & 4.1707 & 51.3133 \\
\hline & 2 & 70 & 31.3071 & 1.7 & 10.4545 & 50.7429 \\
& 3 & 68 & 24.0603 & 2.3824 & 8.9265 & 52.6176 \\
& 4 & 64 & 26.0839 & 1.4531 & 5.6591 & $50.0938 b$ \\
& 5 & 75 & 31.4667 & 2.0267 & 5.4478 & 53.7467 \\
& 6 & 76 & 27.5329 & 1.6184 & 4.2368 & 58.8553 \\
\hline
\end{tabular}

\section{Conclusion}

Genetic variability was observed in all agronomic measured characters of M2 generation after 150 Gy dose of gamma ray treatment. The extent of this variability depends on the genotype's response to gamma irradiation. Cluster analysis results confirm the presence of genetic dissimilarities among the mutant families. The identified mutant families could be used in the future breeding program in cowpea particularly in enhancement programs for Striga resistance and drought tolerance research. 


\section{Conflict of Interests}

The authors have not declared any conflict of interests.

\section{Acknowledgments}

The authors gratefully acknowledge the financial support provided by ICRISAT/TLLIII. Thanks to AIEA who irradiated cowpea seeds and thanks to the members of INERA and of «Laboratoire Biosciences » of « Université Joseph KI-ZERBO » for the reading and correction of the manuscript.

\section{References:}

1. Adekola, O.F. \& Oluleye, F. (2007). Induction of genetic variation in cowpea Vigna unguiculata L.Walp, by gamma irradiation. In Asian Journal of Plant Sciences, 65: 869-873.

2. Amri-Tilioune, W., Laouar, M., Abdelguerfi, A., Jankowicz-Cieslak, J., Jankuloski, L. \& Till, B.J. (2018). Genetic variability induced by gamma rays and preliminary results of low-cost telling on M2 generation of chckpea (Cicer arietinum L.). In Frontier Plant Sciences, 9: 1568.

3. Bado, B.V. (2002). Role des legumineuses sur la fertilite des sols ferrugineux tropicaux des zones guineene et soudanienne du Burkina Faso. Thesis. Faculté des Sciences de l'Agriculture et de l'Alimentation. Université de Laval.

4. Batieno, B.J.T., Souleymane, O., Tignegre, J.-B., Huynh, B.-L., Kusi, F., Poda, S.L. \& Ouedraogo, T. J. (2018). Single nucleotide polymorphism (SNP)-based genetic diversity in a set of Burkina Faso cowpea germplasm. In African Journal of Agricultural Research, 13(19), 978-987. https://doi.org/10.5897/AJAR2018.13121.

5. Dilnesaw, Z., Abadi, S., \& Getahun, A. (2013). Genetic variability and heritability of soybean (Glycine $\max (\mathrm{L})$ Merrill) genotype in Pawe district; Metekel zone, Benishangule Gumuz regional state; northwestern Ethiopia. In Zudpecker journal of agriculture research, vol 2(9), pp. 240-245.ISSN 2315-7259.

6. Elhardallou, S.B., Khalid, I.I., Gobouri, A.A. \& Abdel-Hafez, S.H (2015). Amino Acid Composition of Cowpea (Vigna ungiculata L. Walp) Flour and Its Protein Isolates. In Food and Nutrition Sciences.6. 790-797.

7. Gunasekaran, A. \& Pavadai, P. (2015). Studies on induced physical and chemical mutagenesis in groundnut (Arachis hypogia ). In International Letters of Natural Sciences. 8. 25-35. https://doi.org/10.18052.

8. Kemal, F.A., Fatimah Kayat, F. \& Zakaria, S. (2018). Identification of morphological and molecular variation induced by gamma irradiation 
on musa cv. Pisang tanduk (aab). Pakistan Journal Biotechnologic. Vol. 15 (2) 265-271

9. Kumar, L.V. (2011). Gamma irradiated variability studies in Bambara groundnut (Vigna subterranean (L.) Veedc). Thesis. Department of genetics and plant breeding university of agricultural sciences; Bangalore, 118p.

10. Malek, M. A., Rafii, M.Y., Afroz, S.S., Nath, U.K., \& Mondal, M. (2014). Morphological characterization and assessment of genetic variability, character association, and divergence in soybean mutants. In The Scientific World Journal, Vol 2014,:12p. Article ID 968796, http://dx.doi.org/10.1155/2014/968796.

11. Manggoel, W., Uguru, M. I., Ndam, O. N. \& Dasbak, M. A. (2012). Genetic variability, correlation and path coefficient analysis of some yield components of ten cowpea [Vigna unguiculata (L.) Walp] accessions. In Journal of plant breeding and crop Science; 4(5), 8086. https://doi.org/10.5897/JPBCS12.007

12. Micke, A. (1993). Mutation breeding of grain legumes. In Plant and Soil, 52 (1), pp 81-85.

13. Nair, R. \& Mehta, A.K. (2014). Induced genetic variability in cowpea [Vigna unguiculata (L.) Walp] var. Pusa Komal. In The Bioscan 9 (2): 829-833.

14. Olasupo, F. O.. Ilori, C.O., Forster, B.P. \& Bado, S. (2018). Selection for novel mutation induced by gamma irradiation in cowpea [Vigna unguiculata (L .) Walp.]. In International journal of plant breeding and genetics. 12 (1); 1-12.https://doi.org/10.3923/ ijpbg2018.1.12.

15. Usharani, K.S. \& Kumar, C.R.A (2015). Induced viable mutants in urdbean (Vigna mungo (L.) Hepper. In The Bioscan 10 (3): 1103-1108.

16. Usharani K.S., Ananda Kum C.R. (2016). Estimation of variability, heritability and genetic advance in mutant populations of black gram (Vigna mungo L. Hepper). In SABRAO Journal of Breeding and Genetics 48 (3): 258-26.

17. Zia-Ul-Haq, M., Shahid, S.A., Ahmad, S., Qayum, M. \& Rasool, N. (2012). Mineral contents and antioxidant potential of selected legumes of Pakistan. In Journal of Medicinal Plants Research, 6(32), 47354740. https://doi.org/10.5897/JMPR12.255.

18. Zia-Ul-Haq, M., Ahmad, S., Amarowicz, R. \& De Feo, V. (2013). Antioxidant activity of the extracts of some cowpea (Vigna unguiculata (L) Walp.) cultivars commonly consumed in Pakistan. In Molecules. 18(2). 2005-2017. https://doi.org/10.3390/molecules18022005 